AGRICULTURE

\title{
PHOTOSYNTHETIC ACTIVITY OF BEAN ORDINARY DEPENDING ON WAYS OF SEEDING
}

\author{
${ }^{1}$ Ravshanova Nilufar Adilovna \\ ${ }^{2}$ Usmonov Ikrom Makhmudovich \\ ${ }^{3}$ Chulliev Aziz, Kushakovich \\ ${ }^{4}$ Isroilov Bakhtiyor \\ Tashkent State Agrarian University \\ ${ }^{1}$ Senior Lecturer, Department of Crop Production \\ ${ }^{2}$ Assistant of the Department of Crop Production \\ ${ }^{3}$ Assistant of the Department of Crop Production \\ ${ }^{4}$ Assistant of the Department of Crop Production
}

DOI: https://doi.org/10.31435/rsglobal_sr/31102019/6747

\section{ARTICLE INFO}

Received 18 August 2019

Accepted 12 October 2019

Published 31 October 2019

\section{KEYWORDS}

Common beans, photosynthesis, net productivity of photosynthesis, plant standing density, sowing pattern, seeding rate.

\begin{abstract}
This article studies the influence of sowing methods, schemes, and norms on the formation of leaf area and on the net productivity of photosynthesis of new varieties of common beans. Studies have shown that in variants with high density of standing, the area of leaves on one plant is reduced. The reason for the decline in this indicator is associated with high competition of plants. But on one hectare, this indicator increases due to a larger number of plants. In variants with a low sowing rate per hectare, the leaf area decreases, but in one plant it increases. Studies have also shown the dependence of the net productivity of photosynthesis on sowing methods. An increase or decrease in the seeding rate and a change in seeding methods negatively affect this indicator.
\end{abstract}

Citation: Ravshanova Nilufar Adilovna, Usmonov Ikrom Makhmudovich, Chulliev Aziz Kushakovich, Isroilov Bakhtiyor. (2019) Photosynthetic Activity of Bean Ordinary Depending on Ways of Seeding. Science Review. 8(25). doi: 10.31435/rsglobal_sr/31102019/6747

Copyright: (C) 2019 Ravshanova Nilufar Adilovna, Usmonov Ikrom Makhmudovich, Chulliev Aziz Kushakovich, Isroilov Bakhtiyor. This is an open-access article distributed under the terms of the Creative Commons Attribution License (CC BY). The use, distribution or reproduction in other forums is permitted, provided the original author(s) or licensor are credited and that the original publication in this journal is cited, in accordance with accepted academic practice. No use, distribution or reproduction is permitted which does not comply with these terms.

Introduction. One of the main vital processes of plants is photosynthesis. Photosynthesis arose as a result of adaptation to soil and climatic conditions over time. As a result of photosynthesis, plants accumulate organic matter. The dry matter accumulated during the day relative to the unit area of plants is called plant productivity. The higher the photosynthetic activity, the greater the crop yields. When cultivating field crops, it is necessary to create all conditions so that the leaves of plants have the opportunity to absorb more solar energy. For this, it is necessary to study the influence of methods, schemes and sowing norms on the formation of leaf area and on the net productivity of new varieties of common beans.

The results of the study. Studies have shown that the growth of the leaf area follows a parabolic curve, that is, starting from the phase of the ternate leaf, the growth of the leaf area occurs and reaches its maximum in the phase of flowering and the formation of beans. In the initial phases of development, an increase in leaf area is slow, and during flowering and the formation of beans, an increase in leaf area is rapid. During the period of enhanced bean growth, the leaf area begins to decrease, the leaves of the lower tiers of the plant die off, but the decrease in leaf area does not occur at a rapid pace, therefore, the photosynthetic activity of crops during this period is still close to optimal. In the phase of filling, ripeness 
and full ripeness, the leaves begin to die and by the end of the growing season they completely turn yellow and fall off. A study of the photosynthetic activity of crops showed that the dynamics of leaf area, photosynthetic potential and the net productivity of photosynthesis depend on agrotechnical methods of cultivation. In the Ravot cultivar, the leaf area in the flowering phase, in the variant with row spacing of 45 $\mathrm{cm}$, per $1 \mathrm{~cm}^{2}$ ranged from $0.43-1.73$ thousand $/ \mathrm{cm}^{2}$. In the variant with a high density of standing, the leaf area was less than in the variant with a high nutritional area. At a seeding rate of 740 thousand seeds, the leaf area was 0.43 thousand / $\mathrm{cm} 2$. With a decrease in the seeding rate, the leaf area increased by 0.39 1.3 thousand $/ \mathrm{cm}^{2}$. The maximum leaf area was observed in the variant with a seeding rate of 123.4 thousand seeds / ha, it amounted to 1.73 thousand $/ \mathrm{cm}^{2}$.

When studying the area of leaves per 1 ha, we obtained the following results. The dynamics of leaf area per 1 ha had the opposite tendency. The area of leaves per 1 ha was higher in crops with a high stand density than in variants with a sparse stand density of plants. In the variant with a seeding rate of 740 thousand seeds / ha, the leaf area was 32.04 thousand $\mathrm{m}^{2} /$ ha. With an increase in the feeding area, the leaf area, in the variant with a seed rate of 123 thousand seeds / ha, was 21.31 thousand $\mathrm{m}^{2} /$ ha, which is 10.73 thousand $\mathrm{m}^{2} /$ ha less than in the variant with thickened crops. An increase in the area of nutrition and a decrease in the seeding rate led to a decrease in the area of leaves per 1 ha.

Changing the method of sowing also affected the formation of the leaf area of plants. In the variant with row spacing of $60 \mathrm{~cm}$ on one plant, the leaf area was higher than in the variant with row spacing of $45 \mathrm{~cm}$. The area of leaves on one plant varied from 5.21 to 20.51 thousand $\mathrm{cm}^{2}$.

In the variant with the seeding rate of 555 thousand seeds / ha, the leaf area on one plant amounted to 5.21 thousand $\mathrm{cm}^{2}$, with an increase in the feeding area, in the variant with the seeding rate of 92.2 thousand seeds / ha, the leaf area on one plant was 2051 thousand $\mathrm{cm}^{2}$, which is 15.3 thousand $\mathrm{cm}^{2}$ more than in the variant with a seeding rate of 555 thousand seeds / ha. The area of leaves on 1 single plant with a change in the area of nutrition varied from 9.83 to 15.3 thousand $\mathrm{cm}^{2}$. A high indicator was observed at a sowing rate of 92.2 thousand seeds / ha -20.51 thousand $\mathrm{cm}^{2}$. The study of the formation of leaf area per hectare gave the following results. In the variant with row spacing of $60 \mathrm{~cm}$ per hectare, the leaf area varied from 18.9 to 28.94 thousand $\mathrm{m}^{2}$. In the variant with a seeding rate of 555 thousand seeds / ha, the leaf area was 28.94 thousand $\mathrm{m}^{2}$ / ha, a decrease in the seeding rate to 92.2 thousand seeds / ha, the leaf area was 28.94 thousand $\mathrm{m}^{2}$, which is 10.04 less than in variants with a high plant density. In the variants with row spacing's of $45 \mathrm{~cm}$ and in the variants with row spacing's of $60 \mathrm{~cm}$, we observed the following pattern, plants in variants with a high standing density have less leaf area on one plant than in variants with a low standing density, and on the same hectare we observed the opposite tendency. The leaf area of crops was larger in variants with a high density of standing. A large area of leaves per 1 ha in thickened crops depended on the number of plants per hectare. When comparing varieties, studies showed that the variety "Makhsuldor" has a larger plate area than the variety "Ravot" by $0.5-0.14$ thousand $\mathrm{cm}^{2} / 1$ plant. So, in the variant with a seeding rate of 740 thousand seeds / ha, the leaf area on one plant amounted to 0.47 thousand $\mathrm{cm} 2$, with an increase in the feeding area, we observed such a pattern as in the Ravot variety, that is, the leaf area on one plant increased and in the variant with the seeding rate amounted to 123.4 thousand seeds / ha 1.87 thousand $\mathrm{cm}^{2}$, which is 1.4 thousand $\mathrm{cm}^{2}$ more than in the variant with thickened crops. A study of the leaf area per 1 ha yielded the following results. An increase in the seeding rate per hectare increases the leaf surface area, that is, if in the thickened crops the leaf area on one plant is smaller, then on one hectare on the thickened crops the leaf area increases due to the larger number of plants per 1 ha. So, in the variant with a seeding rate of 740 thousand seeds, the area of the leaf surface of the sowing was 35.27 thousand $\mathrm{m}^{2}$ / ha. Decrease in the seeding rate reduces the area of the leaf surface, in the variant with the seeding rate of 123.4 thousand seeds / ha, the surface area of the leaf is 23.03 thousand $\mathrm{m}^{2} /$ ha.

Table 1. The leaf area of common bean varieties, depending on the agrotechnical methods of cultivation (flowering phase, average 2010-2012)

\begin{tabular}{|c|c|c|c|c|c|c|c|c|c|c|c|c|c|}
\hline \multirow{2}{*}{ № } & \multirow{2}{*}{ Varieties } & \multicolumn{5}{|c|}{ Leaf area by options (thousand $\mathrm{cm}^{2}$ ) } & \multicolumn{5}{|c|}{ Leaf area by options (thousand $\mathrm{m}^{2} / \mathrm{ha}$ ) } \\
\cline { 3 - 15 } & & $45 \times 3$ & $45 \times 6$ & $45 \times 9$ & $45 \times 12$ & $45 \times 15$ & $45 \times 18$ & $45 \times 3$ & $45 \times 6$ & $45 \times 9$ & $45 \times 12$ & $45 \times 15$ & $45 \times 18$ \\
\hline 1 & Ravot & 0,43 & 0,82 & 1,19 & 1,44 & 1,62 & 1,73 & 32,04 & 30,46 & 29,05 & 26,7 & 23,9 & 21,31 \\
\hline 2 & Mahsuldor & 0,47 & 0,87 & 1,23 & 1,46 & 1,66 & 1,87 & 35,27 & 31,97 & 30,54 & 27,07 & 24,61 & 23,03 \\
\hline
\end{tabular}


Table 2. The leaf area of common bean varieties, depending on the agrotechnical methods of cultivation (flowering phase, average 2010-2012)

\begin{tabular}{|c|l|c|c|c|c|c|c|c|c|c|c|c|c|}
\hline \multirow{2}{*}{ № } & \multirow{2}{*}{ Varieties } & \multicolumn{4}{|c|}{ Leaf area by options (thousand $\mathrm{cm}^{2}$ ) } & \multicolumn{4}{c|}{ Leaf area by options (thousand $\mathrm{m}^{2}$ / ha) } \\
\cline { 3 - 14 } & & 60x3 & $60 \times 6$ & $60 \times 9$ & $60 \times 12$ & $60 \times 15$ & $60 \times 18$ & $60 \times 3$ & $60 \times 6$ & $60 \times 9$ & $60 \times 12$ & $60 \times 15$ & $60 \times 18$ \\
\hline 1 & Ravot & 5,21 & 9,83 & 13,82 & 16,71 & 19,59 & 20,51 & 28,94 & 27,14 & 25,56 & 23,22 & 21,55 & 18,9 \\
\hline 2 & Mahsuldor & 5,75 & 10,28 & 14,4 & 18,04 & 20,68 & 21,98 & 31,9 & 28,37 & 26,79 & 25,07 & 22,74 & 20,26 \\
\hline
\end{tabular}

Changing the method of sowing, in variants with row spacing of $60 \mathrm{~cm}$, we observed the following tendency to change the leaf area of plants on common bean. The leaf area in the variants with row spacing of $60 \mathrm{~cm}$ was larger than with the row spacing of $45 \mathrm{~cm}$. The leaf area was $5.75-$ 21.98 thousand $\mathrm{cm}^{2} /$ per 1 plant. A variant with a seeding rate of 555 thousand seeds / ha had a leaf surface of 5.75 thousand $\mathrm{cm}^{2} /$ per 1 plant. A decrease in the seeding rate increased the leaf area on one plant, but on one hectare this indicator was less than in variants with thickened crops. In the variant with a seeding rate of 92.2 thousand seeds / ha, the leaf area was 21.98 thousand $\mathrm{cm}^{2} /$ per 1 plant. In the Makhsuldor variety, as well as in the Ravot variety, we observed the same pattern, with an increase in the feeding area, a decrease in the leaf surface area.

An increase in leaf area with adequate nutrition leads to negative results. In this case, biomass is growing at a rather high rate due to vegetative organs, but the conditions for the formation of fruits and seeds are getting worse. High density of plant standing can lead to similar results. In these variants, at the early stages of phase development, leaves are closed at the top; as a result, the leaves located in the lower part of plants shade and begin to die quickly. Plants in variants with a high density of standing become single-stem, beans are formed only in the upper nodes of the shoot. In variants with a high nutritional area, complete closure of the leaves occurs later, as a result, the plant receives not only direct blessing, but also lateral. Leaves located in the lower tiers do not fall until the end of the growing season.

Data on changes in the net productivity of bean photosynthesis, depending on the methods, schemes, and seeding rates, are given in Table 3-4. The light intensity at different densities of standing is different, the data of our studies indicate that in thickened crops 740 thousand seeds/ha, in variants with row spacing's of $45 \mathrm{~cm}$, the net productivity of photosynthesis in the flowering phase - the formation of beans in the Ravot variety was $4.66 \mathrm{~g} / \mathrm{m}^{2} \times$ day, while in sparse seeding it was $5.87 \mathrm{~g} / \mathrm{m}^{2} \times$ day. It should be noted that a decrease in leaf area increased the net productivity of photosynthesis, but dry weight decreased. We observed a relationship between seeding rates, leaf area, and net photosynthesis productivity.

When changing the row spacing to $60 \mathrm{~cm}$, the net productivity of photosynthesis in the Ravot variety increased and varied from $5.26-6.51 \mathrm{~g} / \mathrm{m}^{2} \times$ day. In variants with a high plant density, the net productivity of photosynthesis was $5.26 \mathrm{~g} / \mathrm{m}^{2} \times$ day. A further decrease in the seeding rate increased the net productivity of crops and, in the variant with a seeding rate of 185.1 thousand seeds, it reached a maximum of $6.51 \mathrm{~g} / \mathrm{m}^{2} \times$ day. In variants with sowing methods, we also observed a pattern and relationship between leaf area and net plant productivity. With an increase in feeding area, the net productivity of plants increases. In variants with row spacing of $60 \mathrm{~cm}$, the net productivity of photosynthesis was higher by $0.6-0.64 \mathrm{~g} / \mathrm{m}^{2} \times$ day.

In the Mahsuldor variety, the net productivity of photosynthesis was higher than in the Ravot variety. In the variant with row spacing of $45 \mathrm{~cm}$, the net productivity of photosynthesis ranged from $4.71-6.68 \mathrm{~g} / \mathrm{m}^{2} \times$ day. In the options with thickened crops, 740 thousand seeds / ha, the net productivity of photosynthesis was low and was $4.71 \mathrm{~g} / \mathrm{m}^{2} \times$ day; an increase in the feeding area increased the net productivity of photosynthesis by $0.54-1.97 \mathrm{~g} / \mathrm{m}^{2} \times$ day. The maximum indicator was achieved with a sowing rate of 148.1 thousand seeds / ha, the net productivity of photosynthesis was $6.68 \mathrm{~g} / \mathrm{m}^{2} \times$ day. A further increase in the feeding area, with a change in the row spacing, as in the Ravot variety, increased the net productivity of photosynthesis. In variants with row spacing of 60 $\mathrm{cm}$, the same pattern was observed as in the previous version. 
Table 3. The net productivity of photosynthesis in the flowering phase is the formation of legumes of common bean varieties, depending on the agrotechnical methods of cultivation

\begin{tabular}{|c|c|c|c|c|c|}
\hline № & $\begin{array}{c}\text { Sowing } \\
\text { pattern }\end{array}$ & $\begin{array}{c}\text { Seeding rate, } \\
\text { thousand seeds / ha }\end{array}$ & $\begin{array}{c}\text { Dry weight, } \\
\mathrm{g}\end{array}$ & $\begin{array}{c}\text { The average area of } \\
\text { leaves, thousand } \mathrm{m}^{2}\end{array}$ & $\begin{array}{c}\text { Pure } \\
\text { photosynthesis } \\
\text { productivity, } \\
\mathrm{g} / \mathrm{m}^{2} \times \text { day }\end{array}$ \\
\hline \multicolumn{5}{|c|}{ Ravot } \\
\hline 1 & $45 \times 3$ & 740 & 16,83 & 48,06 & 4,66 \\
\hline 2 & $45 \times 6$ & 370 & 18,9 & 45,69 & 4,86 \\
\hline 3 & $45 \times 9$ & 247 & 19,1 & 43,575 & 5,51 \\
\hline 4 & $45 \times 12$ & 185,2 & 20 & 40,05 & 5,87 \\
\hline 5 & $45 \times 15$ & 148,1 & 18,24 & 35,85 & 5,65 \\
\hline 6 & $45 \times 18$ & 123,4 & 15,98 & 31,965 & 5,55 \\
\hline \multicolumn{7}{|c|}{ Mahsuldor } \\
\hline 1 & $45 \times 3$ & 740 & 21,2 & 52,905 & 4,71 \\
\hline 2 & $45 \times 6$ & 370 & 21,4 & 47,955 & 5,25 \\
\hline 3 & $45 \times 9$ & 247 & 22,68 & 45,81 & 5,5 \\
\hline 4 & $45 \times 12$ & 185,2 & 23,1 & 40,605 & 6,32 \\
\hline 5 & $45 \times 15$ & 148,1 & 22,2 & 36,915 & 6,68 \\
\hline 6 & $45 \times 18$ & 123,4 & 20,425 & 34,545 & 6,22 \\
\hline
\end{tabular}

Table 4. The net productivity of photosynthesis in the flowering phase is the formation of legumes of common bean varieties, depending on the agrotechnical methods of cultivation

\begin{tabular}{|c|c|c|c|c|c|}
\hline № & $\begin{array}{c}\text { Sowing } \\
\text { pattern }\end{array}$ & $\begin{array}{c}\text { Seeding rate, } \\
\text { thousand seeds } \\
/ \text { ha }\end{array}$ & $\begin{array}{c}\text { Dry } \\
\text { weight, g }\end{array}$ & $\begin{array}{c}\text { The average area of } \\
\text { leaves, thousand } \mathrm{m}^{2}\end{array}$ & $\begin{array}{c}\text { Pure photosynthesis } \\
\text { productivity, } \\
\mathrm{g} / \mathrm{m}^{2} \times \text { day }\end{array}$ \\
\hline \multicolumn{7}{|c|}{ Ravot } \\
\hline 1 & $60 \times 3$ & 555 & 20,58 & 43,41 & 5,26 \\
\hline 2 & $60 \times 6$ & 277,6 & 22,785 & 40,71 & 5,89 \\
\hline 3 & $60 \times 9$ & 185,1 & 23,73 & 38,34 & 6,51 \\
\hline 4 & $60 \times 12$ & 139 & 20,37 & 34,83 & 5,15 \\
\hline 5 & $60 \times 15$ & 110,6 & 18,745 & 32,325 & 5,44 \\
\hline 6 & $60 \times 18$ & 92,2 & 15,435 & 28,35 & 5,35 \\
\hline \multicolumn{7}{|c|}{ Mahsuldor } \\
\hline 1 & $60 \times 3$ & 555 & 25,62 & 47,85 & 6,09 \\
\hline 2 & $60 \times 6$ & 277,6 & 25,935 & 42,555 & 6,44 \\
\hline 3 & $60 \times 9$ & 185,1 & 27,195 & 40,185 & 7,2 \\
\hline 4 & $60 \times 12$ & 139 & 28,455 & 37,605 & 7,08 \\
\hline 5 & $60 \times 15$ & 110,6 & 26,565 & 34,11 & 6,78 \\
\hline 6 & $60 \times 18$ & 92,2 & 22,68 & 30,39 & \\
\hline
\end{tabular}

At a seeding rate of 555 thousand seeds, the net productivity of photosynthesis was $5.35 \mathrm{~g} /$ $\mathrm{m} 2 \times$ day, with a decrease in the seeding rate, the net productivity of photosynthesis increased by 0.74 $-1.85 \mathrm{~g} / \mathrm{m} 2 \times$ day.

We observed a high indicator of the net productivity of photosynthesis in the variant with a seeding rate of 139 thousand seeds / ha.

An increase or decrease in the seeding rate and plant density affected the formation of the leaf area of crops and the net productivity of photosynthesis.

Conclusions. 1. The increase in leaf area of crops directly depended on the density of plant standing;

2. In variants with thickened crops at the early stages of phase development, leaves are closed at the top, as a result of which the leaves located in the lower part of the plants are shaded and begin to die off quickly, which leads to a decrease in the leaf area of crops;

3. In variants with a high nutritional area, complete closure of the leaves occurs later, as a result, the plant receives not only direct blessing, but also lateral. Leaves located in the lower tiers do not fall until the end of the growing season; 
4. A high indicator of the net productivity of photosynthesis was in the variant with row spacing of $60 \mathrm{~cm}$;

5. Increasing or decreasing the seeding rate increased and decreased the net productivity of photosynthesis; variety.

6. In all indicators of photosynthetic activity, the Ravot variety was inferior to the Makhsuldor

\section{REFERENCES}

1. Антонов О.В. и др. Фотосинтетический потенциал обыкновенной фасоли на капельном орошении //Вестник ОрёлГАУ 6 (36) декабрь 2016. С 67 - 70

2. Оборский С.Л., «Разработка элементов технологии возделования фасоли обыкновенной в условиях среднего Приамурье», Благровещенск. Автореферат канд.дисс 2006. С - 118

3. Овчарук О. В.,Околодько Ю. В. Влияние способов посева и норм высева семян на урожайность сортов фасоли в условиях лесостепи Украины Научно - производственный журнал «Зернобобовые и крупяные культуры» №4(20)2016 г. С - 60

4. Попов В.П. Фасоль обыкновенная (Phaseolus vulgaris L.) в условиях юга Московской области / В.П. Попов // Нетрадицион. с.-х., лекарств. и декоративные растения. - 2003. - № 1. - С. 17-29.

5. Русаков В.В. Продуктивность фотосинтеза сои при разных способах питания азотом / В.В. Русаков, А.А. Алябьева, Ю.В. Медведев // Вопросы повышения плодородия почв и урожайности с.-х. культур в Амурской области. - Благровещенск, 1980. - С. 70-76.

6. Седов А.И. Фасоль при орошении на темно-каштановых почвах Саратовского Заволжья. Прогессивная технология возделывания и уборки зернобобовых культур. Орел, 1971. С - 173 